\section{HLA Bw35 antigen and human reproduction}

SIR,

That the HLA system plays an important part in the maternal-fetal relationship has been postulated by several investigators. ${ }^{1-5}$ Finn suggested that these antigens might serve as cell surface 'repellents', contributing to the survival of the fetal allograft. ${ }^{6}$ A possible linkage of the HLA locus with differentiation alloantigens has also been suggested by Erickson. ${ }^{7}$ Abnormalities or absence of such antigens could be associated with failures of embryogenesis and birth defects.

Kamidono et $\mathrm{al}^{8}$ recently reported a high incidence of Bw35 antigen in couples with unexplained infertility. Komlos and co-workers ${ }^{9}$ in 1977 observed that a higher frequency of common HLA antigens was shared by both members of couples who had had repeated miscarriages compared to controls. From their data, it also appears that the incidence of Bw35 in wives $(45.4 \%)$ is higher than in husbands $(35.0 \%)$.

Thirty-five couples from Rome who had had repeated miscarriages (number of consecutive miscarriages $\geqslant 3$ ) were studied. Routine clinical investigations, both morphological and functional, were negative. Eighteen couples with unexplained infertility were also examined.

The distribution of Bw35 antigen in couples with repeated miscarriage, in couples with infertility, and in a control sample from the same population, separately for females and males, is shown in the table. Females with repeated miscarriages or sterility show a higher incidence of Bw35 compared to males and to controls.

Bw35 antigen has been reported in association with thyrotoxicosis (in Japan), subacute thyroiditis, ${ }^{10}$

TABLE Distribution of Bw35 antigen in couples with repeated miscarriages, in couples with sterility, and in a random sample of normal adults from the same population.

\begin{tabular}{lllll}
\hline & & $\begin{array}{l}\text { Bw35 } \\
\text { Present }\end{array}$ & Absent & \% positive \\
\hline Repeated & Females (A) & 18 & 17 & 51.4 \\
miscarriage & Males (B) & 9 & 26 & 25.7 \\
Sterility & Females (C) & 7 & 11 & 38.9 \\
& Males (D) & 4 & 14 & 22.2 \\
Normal adults & Females (E) & 33 & 72 & 31.4 \\
\hline
\end{tabular}

Comparisons: $A$ vs $B, p<0.03 ; C$ vs $D, N S ;(A+C)$ vs $(B+D)$, $\mathrm{p}<0.02 ; A$ vs $\mathrm{E}, \mathrm{p}<0.05 ;(A+C)$ vs $E, p \sim 0.05$. and non-streptococcal (probably viral) glomerulonephritis. ${ }^{11}$ The present data suggest that this antigen may also be important in human reproduction, and further investigations into its role in the maternal-fetal relationship and intrauterine development are needed.

\section{Maria Purpura, Isa Coghi, Maria Nicotra, ERminia Carapella, aNd E. Bottini Central Laboratory of Blood Transfusion, Italian Red Cross; Departments of Obstetrics and Child Health, University of Rome; and \\ Department of Genetics, University of Camerino,} Italy

\section{References}

1 Clarke B, Kirby DRS. Maintenance of histocompatibility polymorphisms. Nature 1966;211:999-1000.

2 Billington WD. Immunological processes in mammalian reproduction. In: Adinolfi $\mathrm{M}$, ed. Immunology and development. London: Spastic International Medical Publishers, $1969: 89-113$.

3 Ceppellini R. Old and new facts and speculations about transplantation antigens of man. In: Progress in immunology. New York: Academic Press, 1971:973-1025.

4 Amos DB, Bodmer WF, Ceppellini R, et al. Biological significance of histocompatibility antigens. Fed Proc 1972; $31: 1087-104$.

5 Beer AE, Billingham RE. Immunoregulatory aspects of pregnancy. Fed Proc 1978;37:2374-8.

6 Finn R. Survival of the genetically incompatible fetal allograft. Lancet 1975;1:835-8.

7 Erickson RP. Differentiation alloantigens, histocompatibility loci, and birth defects. Am J Hum Genet 1975; 27:554-7.

8 Kamidono S, Mayumi K, Tanikaze S, Ishigami J, Isojima $S$, Tsuji $K$. HLA antigens in male sterility and infertile couples (in Japan). In: Abstract 5th European Congress on Sterility and Fertility. Rome: Minerva Medica, 1978:196.

9 Komlos L, Zamir RJ, Halbrecht I. Common HLA antigens in couples with repeated abortions. Clin Immunol Immunopathol 1977;7:330-5.

10 Svejgard A, Ryder LP. HLA and disease. In: Ferrara $\mathrm{GB}$, ed. HLA system-new aspects. Amsterdam: Elsevier, $1977 ; 143-51$.

11 HLA and disease: a conundrum. $\mathrm{Br}$ Med J 1976;2:546-7.

\section{Multiple polyposis of the colon}

SIR,

The paper by Lynch et al (J Med Genet 1979; 16: 1-7), proposing that the autosomal dominant gene for multiple polyposis of the colon could sometimes express itself as a solitary adenocarcinoma, brought to mind a family $I$ first saw in 1954. By now 6 of 7 